\title{
Chip, a widely expressed chromosomal protein required for segmentation and activity of a remote wing margin enhancer in D rosophila
}

\author{
Patrick Morcillo, Christina Rosen, Mary K. Baylies, and Dale Dorsett ${ }^{\mathbf{1}}$ \\ M olecular Biology Program, Sloan-Kettering Institute for Cancer Research, M emorial Sloan-Kettering Cancer Center, \\ N ew York, N ew York 10021 USA
}

The mechanisms al lowing remote enhancers to regulate promoters several kilobase pairs away are unknown but are blocked by the D rosophila suppressor of Hairy-wing protein (Suhw) that binds to gypsy retrovirus insertions between enhancers and promoters. Suhw bound to a gypsy insertion in the cut gene also appears to act interchromosomally to antagonize enhancer-promoter interactions on the homologous chromosome when activity of the $\mathrm{C}$ hip gene is reduced. This implicates $\mathrm{C}$ hip in enhancer-promoter communication. We cloned $\mathrm{Chip}$ and find that it encodes a homolog of the recently discovered mouse $\mathrm{Nli} / \mathrm{Ldbl} / \mathrm{Clim}-2$ and Xenopus XIdb1 proteins that bind nuclear LIM domain proteins. Chip protein interacts with the LIM domains in the Apterous homeodomain protein, and $\mathrm{C}$ hip interacts genetically with apterous, showing that these interactions are important for Apterous function in vivo. Importantly, Chip also appears to have broad functions beyond interactions with LIM domain proteins. Chip is present in all nuclei examined and at numerous sites along the salivary gland polytene chromosomes. Embryos without Chip activity lack segments and show abnormal gap and pair-rule gene expression, although no LIM domain proteins are known to regulate segmentation. We conclude that $\mathrm{Chip}$ is a ubiquitous chromosomal factor required for normal expression of diverse genes at many stages of development. We suggest that Chip cooperates with different LIM domain proteins and other factors to structurally support remote enhancer-promoter interactions.

[Key Words: apterous; even-skipped; gap genes; homeodomain; LIM domain-binding protein; suppressor of Hairy-wing]

Received June 27, 1997; revised version accepted August 12, 1997.

Development of multicellular organisms requires precise temporal and spatial regulation of gene expression. Much of this regulation depends on proteins that bind transcription enhancers. For enhancers separated by a few hundred base pairs from their promoter, DN A Iooping may be sufficient to al low interactions between basal factors at the promoter and the enhancer-binding proteins. Many complex devel opmentally regulated genes, however, contain multiple enhancers, which can be many kilobase pairs from the promoter. Enhancers require more than DN A looping to interact with the promoter over such remote distances. For instance, either a UAS or a higher eukaryotic enhancer must be upstream and promoter-proximal to activate transcription in yeast cells, yet both will function downstream of the gene in higher eukaryotic cells (Struhl 1989). This suggests that, in contrast to yeast, higher eukaryotes have factors that facilitate remote enhancer-promoter interactions.

${ }^{1}$ Corresponding author.

E-MAIL d-dorsett@ski.mskcc.org FAX (212) 717-3623.
The effects of insertions of the gypsy retrovirus on enhancer activity in Drosophila lend support to the enhancer-facilitator hypothesis. Gypsy insertions block enhancer-promoter communication, without inactivating either the enhancer or promoter, when, and only when, they are between the enhancer and promoter (for review, see Dorsett 1996; Geyer 1997). The Suhw protein encoded by suppressor of Hairy-wing [su(H w)] that binds to specific sequences in gypsy insertions is necessary and sufficient to block enhancers.

A common domain in Suhw is required for gypsy insertions to block enhancers in several different genes (Harrison et al. 1993; Kim et al. 1996), suggesting that Suhw blocks all enhancers by the same mechanism. Enhancer blocking is distance independent and reversible (Dorsett 1993), and blocked enhancers remain active because they can activate a second promoter in the other direction (Cai and Levine 1995; Scott and Geyer 1995). These observations rule out an epigenetic chromatin structure, or interference with enhancer-binding factors as blocking mechanisms. Although Suhw distorts DNA 
(Shen et al. 1994), this is not sufficient to block enhancers in Drosophila (Kim et al. 1996) or an upstream activating sequence (UAS) in yeast (Kim et al. 1993). We postulate, therefore, that the Suhw enhancer-blocking domain interacts and interferes with higher eukaryotic proteins that facilitate interactions between the enhancer and promoter. We envision that enhancer-facilitators hel p form chromatin structures that bring enhancers and promoters closer together, and that they are different from enhancer-binding activators, coactivators, and basal factors in that they do not partici pate directly in the activation reaction. It can be inferred that the facilitating chromatin structure needs to be continuous, without interruptions, from the ability of Suhw to block the wing margin enhancer in cut from positions scattered throughout the 85-kb region between the enhancer and promoter (Jack et al. 1991), as well as the observation that blocking by gypsy insertions near the cut promoter or wing margin enhancer is qualitatively and quantitatively identical (Dorsett 1993).

To identify potential enhancer-facilitators, we conducted a screen for mutations that reduce activity of the remote wing margin enhancer in the cut locus (M orcillo et al. 1996a). The screen identified two known genes, scalloped (sd) and mastermind (mam), and a novel gene, Chip. The data suggest that sd and mam encode enhancer-binding factors and that Chip may encode an enhancer-facilitator. Both sd and mam mutants display stronger genetic interactions with wing margin enhancer deletions than with gypsy insertions in cut, consistent with roles as transcription activators (Fig. 1). Supporting this view, the sd protein (Sd) is homol ogous to the TEF-1 mammalian enhancer-binding factor (Campbell et al. 1992) and binds several sites in the wing margin enhancer DN A (M orcillo et al. 1996a), whereas Mam protein binds a limited number of sites in polytene chromosomes, including one near the cut locus (Bettler et al. 1996).

Chip is also needed for wing margin enhancer activity, but appears to play a unique role (M orcillo et al. 1996a). Chip mutations dominantly enhance the mutant phenotypes displayed by partially suppressed gypsy insertions in both cut and Ultrabithorax (U bx) and are homozygous larval lethal, indicating that $\mathrm{Chip}$ regulates multiple genes. Chip is normally required for wing margin enhancer function because $C$ hip mutations al so enhance the cut wing phenotype of a cut mutation that lacks a gypsy insertion, and flies wild type for cut and heterozygous for Chip display cut wing phenotypes when either sd or mam are also heterozygous mutant. In contrast to sd and mam mutants, however, Chip mutants display stronger genetic interactions with gypsy insertions than with wing margin enhancer del etions. Thus, in a heterozygous Chip mutant, a heterozygous gypsy insertion in cut displays a cut wing phenotype, whereas a heterozygous enhancer del etion does not (Fig. 1). Dependence on the nature of the heterozygous lesion in the regulatory regi on strongly suggests that Chip directly regulates cut. More strikingly, it indicates that in a Chip heterozygote, a gypsy insertion is more deleterious to enhancer func-

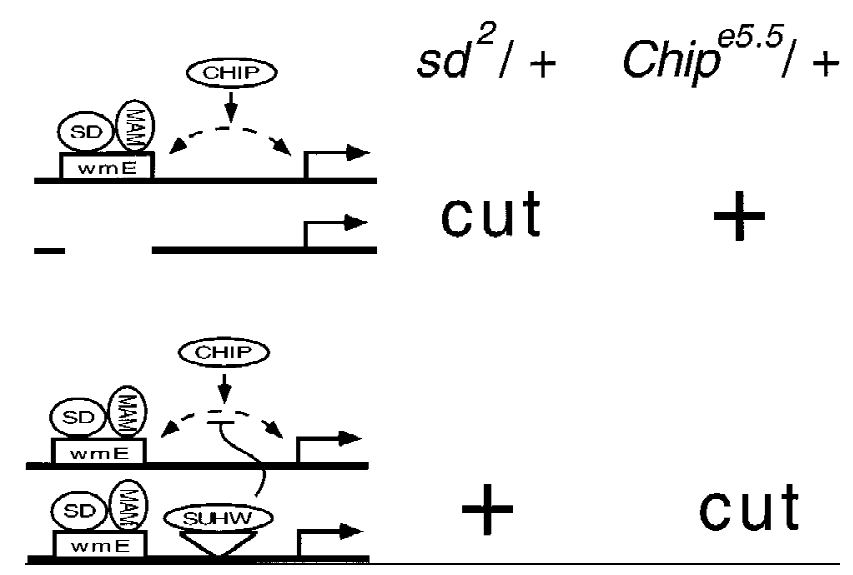

Figure 1. Model for regulation of cut by the remote wing margin enhancer and the sd, mam, and Chip genes. The model summarizes previous genetic and biochemical data (M orcillo et al. 1996a). The regulatory regions of cut genes (not to scale) are shown with the wing margin enhancer (wmE) to the left and the promoter (angled arrow) to the right. The sd protein (Sd) binds wing margin enhancer DNA and mam protein (Mam) is also postulated to be an enhancer-binding factor (see text). In femal es heterozygous for wild-type cut and an enhancer deletion allele (top pair), a heterozygous sd mutation $\left(\mathrm{sd}^{2} /+\right.$ ) causes a partial cut wing phenotype (cut), while a heterozygous Chip mutation $\left(\right.$ Chip ${ }^{\text {e5.5 }} /+$ ) displays wild-type wings $(+)$. In contrast, when a female is heterozygous for wild-type cut and a gypsy insertion allele (bottom pair), which binds the enhancer-blocking su(Hw) protein (Suhw), a heterozygous sd mutation displays wild-type wings whereas a heterozygous Chip mutation causes a partial cut wing phenotype. These results, taken together, indicate that Suhw on one chromosome interferes with enhancer-promoter communication on both chromosomes and that Chip protein (Chip) facilitates enhancer-promoter communication.

tion than deletion of the enhancer. The simplest explanation is that Suhw bound to gypsy in one cut al lele acts in a transvection-like manner to block the wing margin enhancer in the wild-type cut allele on the other chromosome (Fig. 1). This implies that Chip plays a crucial role in enhancer-promoter communication.

If Chip encodes an enhancer-facilitator as suggested by genetics, its products should be widely expressed, be localized in the nucleus, and affect expression of multiple genes. We cloned Chip to address these questions. On the basis of sequence and physical interactions, Chip is a homolog of vertebrate factors that interact with the LIM domains of nuclear proteins. Our results also indicate that beyond the specific interaction with LIM domain proteins, Chip is a ubiquitous chromosomal protein required for gene expression beginning early in embryogenesis.

\section{Results}

Cloning Chip by transposon tagging

Chip maps by recombination to 2-106.8 between orange and speck near the tip of chromosome 2R (M orcillo et al. 
1996a). In a screen with $\gamma$ rays, we isolated a deficiency, Df(2R)Chipg ${ }^{9230}$, that deletes Chip. The visible breakpoints of Chipg230 $(60 \mathrm{~A} 3,7 ; 60 \mathrm{~B} 4,7)$ correlate well with the recombination mapping.

A lethal P-element insertion listed in FlyBase, I(2)k04405 (Torok et al. 1993), was localized by in situ hybridization to 60B1-2, in the region deleted by Chip ${ }^{9230}$. I(2)k04405 fails to complement the larval lethality of Chip mutants. Like Chip mutations (M orcillo et al. 1996a), I(2)k04405 al so dominantly enhances the cut wing phenotype displayed by partially suppressed gypsy insertions in cut (not shown). To test whether the $P$ insertion is the $C$ hip mutation, we generated excisions with a P-transposase source (CyO , HOP2) by scoring for Ioss of the mini-white (w) marker in the P element. Of three independent excisions, two lost Chip lethality, confirming that the $P$ insertion is a Chip mutation.

The I(2)k04405 P-lacW insertion contains a bacterial plasmid origin and ampicillin resistance gene (Bier et al. 1989). The $P$ insertion and $4.5-\mathrm{kb}$ of flanking genomic sequences were rescued from genomic DN A by Sacll digestion, ligation, and transformation of Escherichia coli. The genomic DN A flanking the $P$ element was used to probe $\mathrm{P} 1$ phage inserts that contained DNA from the $60 \mathrm{~A}$ to $60 \mathrm{~B}$ cytological region (Hartl et al. 1994). This probe hybridized to a singl e 10-kb EcoRI fragment in the DS00543 phage insert.

Smaller fragments were subcloned from the $10-\mathrm{kb}$ EcoRI fragment and used to probe $N$ orthern blots of RNA from wild-type and Chip mutant second and third instar larvae. An antisense RN A probe made from a 1-kb EcoO 109-BamHI fragment (Fig. 2A) near the I(2)k04405 $P$ insertion detected a $2.2-\mathrm{kb}$ polyadenylated RNA reduced $\sim 50 \%$ in two heterozygous Chip mutants, Chip ${ }^{9371}$ and the Chip ${ }^{9230}$ deficiency. The 7-kb BglllEcoRI genomic fragment containing the probe fragment (Fig. $2 A$ ) rescues $C$ hip ${ }^{\text {e5.5 }}$ lethality when introduced into the genome by $\mathrm{P}$ element-mediated germ-line transformation, indicating that it contains the essential portions of the gene. We conclude that the $2.2-\mathrm{kb}$ RNA is the Chip mRNA.

A CDN A library from imaginal discs was probed with the 1-kb EcoO109-BamHI genomic fragment (Fig. 2A) that detects the 2.2-kb RNA, and eight clones were isolated. Several had the same $5^{\prime}$ end, and others had the same $3^{\prime}$ end. The few clones containing both the common $5^{\prime}$ and $3^{\prime}$ ends were sequenced, revealing a long open reading frame (ORF) (Fig. 2A) and a poly(A) tail. The ORF encodes a protein of 577 amino acids (Fig. 2B). Comparison of the CDNA and genomic DNA sequences revealed a single small intron upstream of the ORF and that the I(2)k04405 P-insertion site is a few base pairs upstream of the splice acceptor site (Fig. 2A).

To determine the molecular basis of the Chip ${ }^{\mathrm{e} .5}$, Chip ${ }^{9371}$, and Chip ${ }^{91}$ alleles, the ORF was amplified by PCR from genomic DNA isolated from homozygous mutant second instar larvae. All three mutations are small deletions that shift the reading frame. The locations of these deletions are indicated in Figure 2A. Conceptual translation indicates that Chip ${ }^{\mathrm{e} 5.5}$ encodes a 153 amino

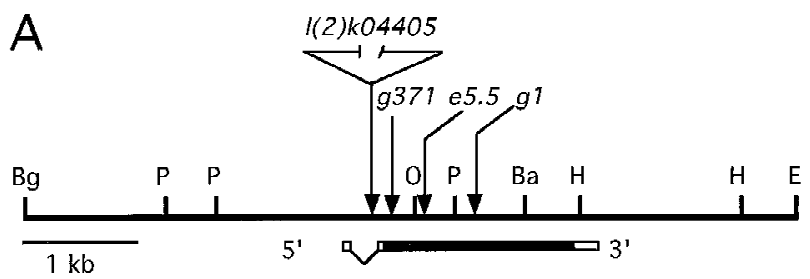

B

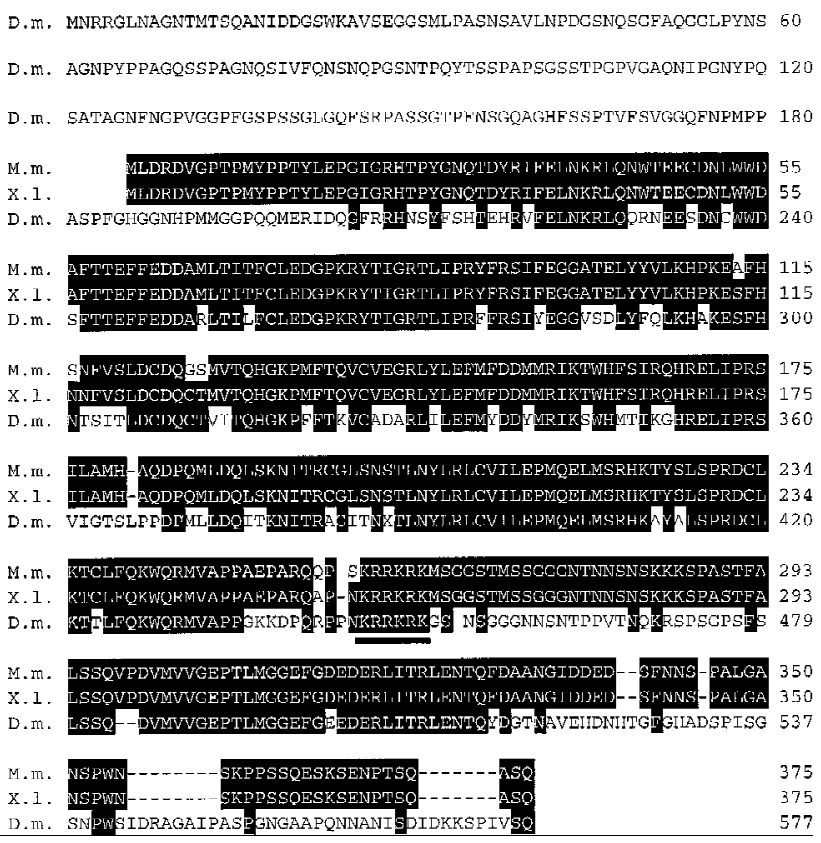

Figure 2. The Chip gene and predicted Chip protein sequence. (A) Structure of the Chip gene. Shown is the restriction map of the 7-kb BglII-EcoRI genomic DNA fragment that rescues Chip homozygous mutant larval lethality. (Ba) BamHI; (Bg) BgllI; (E) EcoRI; (H) HindlII; (O) EcoO 109; (P) Pstl. Locations of the I(2)k04405 P insertion, and the small deletions in Chip ${ }^{\mathrm{e} .5}$, Chip ${ }^{9371}$, and $\mathrm{Chip}^{\mathrm{g1}}$ are indicated by arrows. The boxes below indicate the sequences present in the Chip CDNA clones, with the solid box indicating the ORF. The intron is indicated by $a \mathrm{~V}$. The Chip wild-type and mutant sequences have been deposited in GenBank (accession nos. AF010325-AF010328). (B) Sequence of Chip (D.m.) compared with the vertebrate homologs XIdb1 (X.I.) and Nli/Ldb1/Clim-2 (M.m.). Identities are silhouetted. The putative nuclear localization signal is underlined.

acid protein in which the first 141 are the same as wild type. Chip ${ }^{91}$ encodes a 365-amino-acid protein, in which the first 300 are the same as wild type, and Chip p371 $^{93}$ encodes a 182-amino-acid protein, in which the first 68 are wild type. These lesions confirm the identity of the Chip ORF.

Chip is a functional homolog of vertebrate nuclear LIM domain-binding proteins

The protein encoded by the Chip ORF is homologous to the mouse N li/Ldb1/Clim-2 (Agulnick et al . 1996; Jurata 
et al. 1996; Bach et al. 1997), mouse Clim-1 (Bach et al. 1997), and frog XIdb1 (Agulnick et al. 1996) vertebrate proteins that bind to the LIM domains of nuclear proteins. Chip residues $205-577$ display $58 \%$ identity with the mouse $\mathrm{Nli} / \mathrm{Ldb} 1 / \mathrm{Clim}-2$ protein (Fig. 2B). All of these proteins have a potential nuclear localization signal (Fig. 2B). There are no yeast homologs of Chip, suggesting that Chip and its relatives are specific to higher eukaryotes.

The major difference between Chip and the vertebrate homologs is that $C$ hip has a prol ine-rich amino-terminal domain of $\sim 200$ amino acids (Fig. 2B). Thus, the truncated protein encoded by Chip ${ }^{\mathrm{e} .5}$ does not contain the conserved domain, consistent with the observation that it behaves like a null allele (Morcillo et al. 1996a).

The Nli/Ldb1/Clim-2, Clim-1, and XIdb1 proteins were isolated because they physically interact with nuclear LIM domains (Agulnick et al. 1996; Jurata et al. 1996; Bach et al. 1997). There are mutants available for the apterous (ap) gene in Drosophila, which encodes a LIM-homeodomain (HD) protein involved in wing and muscle development (Bourgouin et al . 1992; Cohen et al. 1992). We tested whether Chip interacts genetical ly with ap. Flies heterozygous for either Chip ${ }^{\mathrm{e} .5}$ or $\mathrm{ap}^{56 f}$ have normal wings, but flies heterozygous for both display margin defects (Fig. 3A). Chip ${ }^{\mathrm{e} .5} / \mathrm{ap}^{56 f}$ male progeny of Chip ${ }^{25.5}$ mothers and $a^{56 f}$ fathers have $2.5 \pm 0.1$ ( $n=261$; error value is the standard error) margin gaps per fly, whereas progeny with the same genotype from $\mathrm{ap}^{56 \mathrm{f}}$ mothers and Chi $\mathrm{p}^{\mathrm{e} .5}$ fathers have $1.0 \pm 0.2(\mathrm{n}=47)$ gaps per fly. Chi p $\mathrm{e}^{\mathrm{5} .5}$ al so interacts with $\mathrm{ap}^{4}$ (not shown). We believe it is unlikely that Ap directly regulates the cut wing margin enhancer because Ap is detected only in the dorsal half of the cells in which this enhancer is active (Blair 1993).

The interaction between Chip and ap and the homology between Chip and the vertebrate LIM domain-binding proteins raised the question of whether Chip interacts directly with the Ap LIM domains. This was tested in a yeast double-hybrid fusion experiment, in which full-length Chip was fused to the bacterial LexA DNAbinding protein, and the Ap LIM domains were fused to the transcription activation domain of the yeast GAL4 protein. The two fusion proteins were coexpressed in a yeast strain containing two reporter genes with LexAbinding sites in the promoter (Hollenberg et al. 1995). One reporter expresses the lac $Z$ gene detected by $X$-gal staining, and the other expresses the HIS3 gene, detected by selection on media lacking histidine. When the two fusion proteins are coexpressed, both reporters are activated (Fig. 3B). The reporters are not expressed when the GAL4 activation domain alone, or the GAL4 activation domain fused to Chip, is coexpressed with the LexAChip fusion. We conclude that Chip interacts with the Ap LIM domains.

\section{CHIP is a widely expressed chromosomal factor}

Ap is expressed in a tissue-specific pattern during development (Bourgouin et al. 1992; Cohen et al. 1992). If

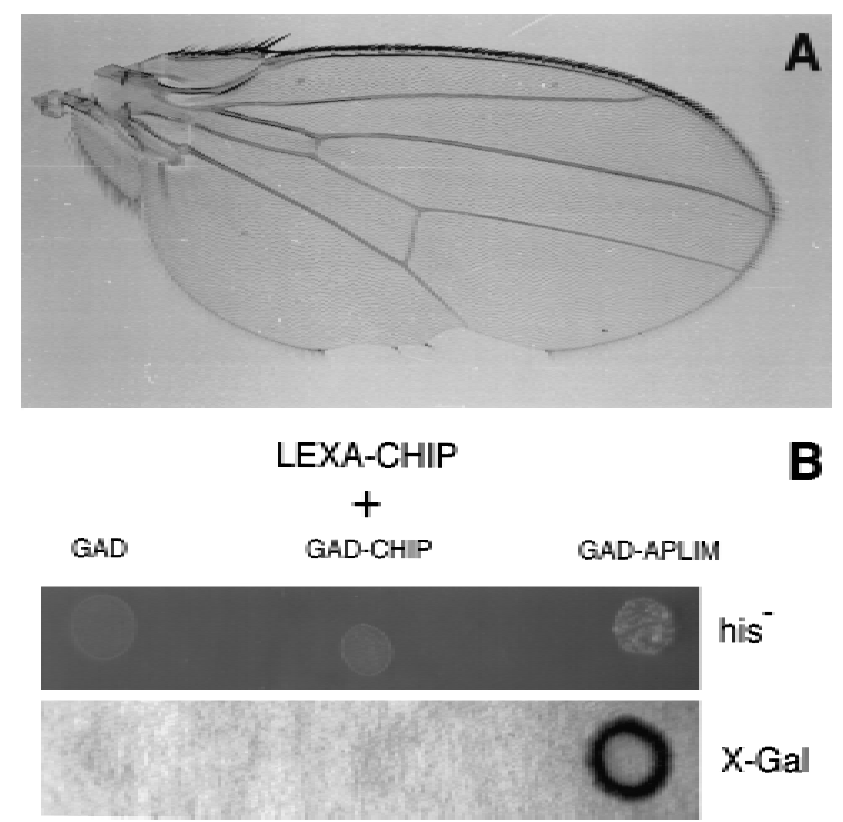

Figure 3. Interactions between Chip and the Ap LIM protein. (A) Genetic interaction between Chip and ap. The wing from a $\mathrm{y}^{*} \mathrm{w}^{*}$; Chip $\mathrm{p}^{\mathrm{e} .5} / \mathrm{ap}^{56 \mathrm{f}}$ male has gaps in the posterior margin. (B) Interaction between Chip and the Ap LIM domain in yeast. Yeast were transformed with a plasmid expressing the full length Chip ORF with the lexA DNA-binding protein fused to the amino terminus, and a second plasmid expressing the indicated protein containing the Gal4 activation domain (GAD, Gal 4 activation domain al one; GAD-Chip, the Gal4 activation domain fused to the Chip ORF; GAD-APLIM, the Gal 4 activation domain fused to the amino terminus of the Ap LIM domains). Interaction between Chip and the Ap LIM domains is indicated by the activation of the lexA operator-HIS3 reporter gene as detected by growth on histidine omission plates (his-), and expression of the lexA operator-lacZ fusion gene as detected by X-Gal staining (X-Gal). The GAD-APLIM protein does not activate the reporters when coexpressed with the LexA DNA-binding domain alone (not shown).

Chip, as suggested by genetic studies, plays a more general role in gene expression than regulating Ap activity, it should be more widely expressed. A Northern blot of total RNA reveals that Chip mRNA is present at all developmental stages (Fig. 4). Strikingly, early embryos (030 min old, lane EE) have 10-fold higher levels than later developmental stages. Because this is before zygotic gene expression, we conclude that Chip mRNA is maternally contributed during oogenesis.

To investigate expression of Chip protein, anti-Chip antibodies were raised in rabbits. The Chip CDNA was expressed in E. coli, producing a 70-kD protein used as antigen. Affinity-purified antibodies recognize a major band of $68 \mathrm{kD}$ and minor bands of 82 and $22 \mathrm{kD}$ in Western blots (not shown) of proteins extracted with $0.35 \mathrm{M}$ $\mathrm{NaCl}$ from nuclei of cultured Schneider 2 Drosophila cells (Dorsett 1990). Embryos stained with these antibodies reveal that from the early cellular blastoderm stage (Fig. 5A) through gastrulation (Fig. 5C) to the end of 


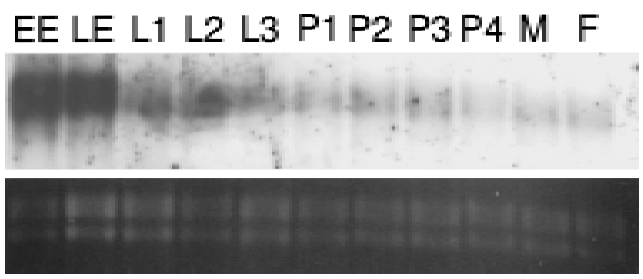

Figure 4. Expression of Chip transcripts during development. (top) An autoradiograph of a N orthern blot showing the Chip 2.2-kb mRN A; (bottom) a photograph of the ethidium bromidestained rRNA in the gel used for the N orthern blot. Each lane contained $5 \mu \mathrm{g}$ of total RNA isolated from Oregon-R wild-type flies at the indicated developmental stage [EE, 0-30 min after egg laying (AEL); LE, 30 min to $16 \mathrm{hr}$ AEL; L1-L3, first to third instar larvae; P1-P4, first to fourth day of pupation; $\mathrm{M}$, 0 - to 1-day old male adults; F, 0- to 1-day old adult females]. Chip transcript was quantitated by Phosphorlmager and normalized to the amount of rRNA as determined by densitometry. After normalization, the Chip transcript level in early embryos (EE) is $\sim 5$-fold higher than in late embryos (LE) and 10-fold higher than in larval and pupal stages.

embryogenesis (not shown), Chip protein is present in most, if not all, nuclei, including the pole cell nuclei. Staining is undetectable or very weak in syncytial blastoderm nuclei until just before cellularization (not shown) although Chip must be present at low levels, because lack of Chip activity affects expression of seg- mentation genes at this stage (see below). Embryos produced from germ-line clones homozygous mutant for Chip ${ }^{e 5.5}$ (see below) do not stain at any stage (Fig. 5B), showing that the staining is Chip-specific. Chip is also present in the nuclei of larval tissues including imagi nal discs (Fig. 5D-F), fat body (Fig. 5G), and salivary glands (Fig. 5H). These observations indicate that Chip is essentially a ubiquitous nucl ear factor during embryogenesis and larval development.

Examination of the larval salivary gl ands stained with anti-Chip antibodies reveal ed that the polytene chromosomes stain in banded patterns (Fig. 5I). From examination of several nuclei, it is evident that $C$ hip is present at many sites al ong the entire lengths of all chromosomes. The nucleoli and nonchromosomal portions of the nuclei do not display significant staining. Attempts to stain the polytene chromosomes after spreading were unsuccessful, indicating that the reagents used to spread the chromosomes either denature the Chip epitopes or remove Chip from the chromosomes. Although we cannot identify the specific loci with which Chip associates, the very large number of sites with which Chip associates is consistent with a general role in gene expression.

\section{Chip is required for accurate expression of} segmentation genes

Most homozygous Chip mutants die prior to the third instar larval stage (M orcillo et al. 1996a). If Chip is re-

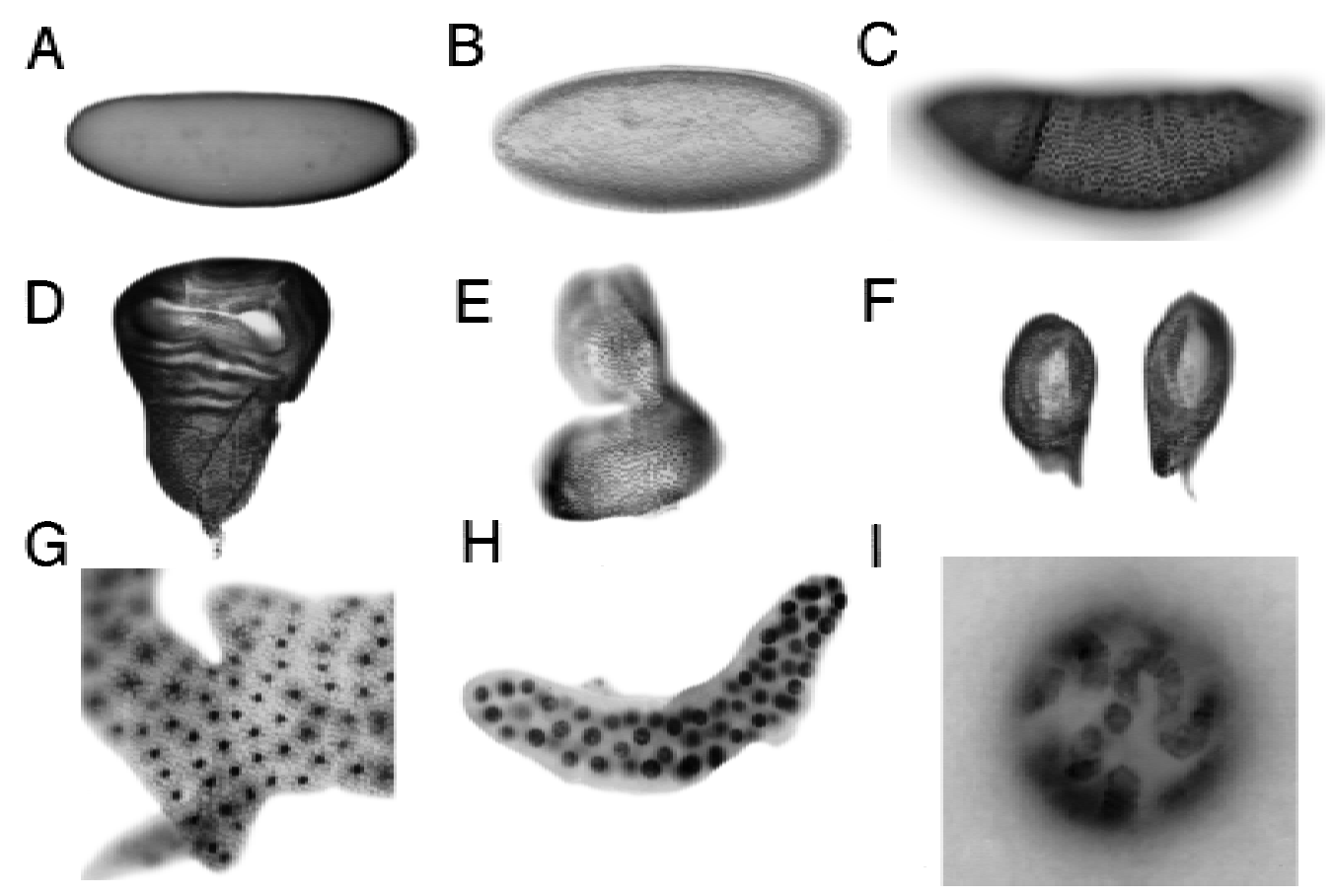

Figure 5. Expression of Chip protein. Embryos and larval tissues were stained with affinity-purified anti-Chip antibodies. All panels are wild-type Oregon-R and the same magnification unless indicated otherwise. Embryos are lateral views with anterior to the left and dorsal to the top. All larval tissues are from third instar larvae. (A) Cellular blastoderm; (B) mutant cellular blastoderm from Chip ${ }^{\text {e5.5 }}$ germ-line clone; (C) gastrula; (D) wing imaginal disc; (E) eye-antennal imaginal disc; (F) leg imaginal discs; (G) larval fat body; (H) larval sal ivary gland; (I) sal ivary gl and nucl eus at 10-fol d higher magnification than in panel $\mathrm{H}$. The polytene chromosomes stain in a banded pattern. 

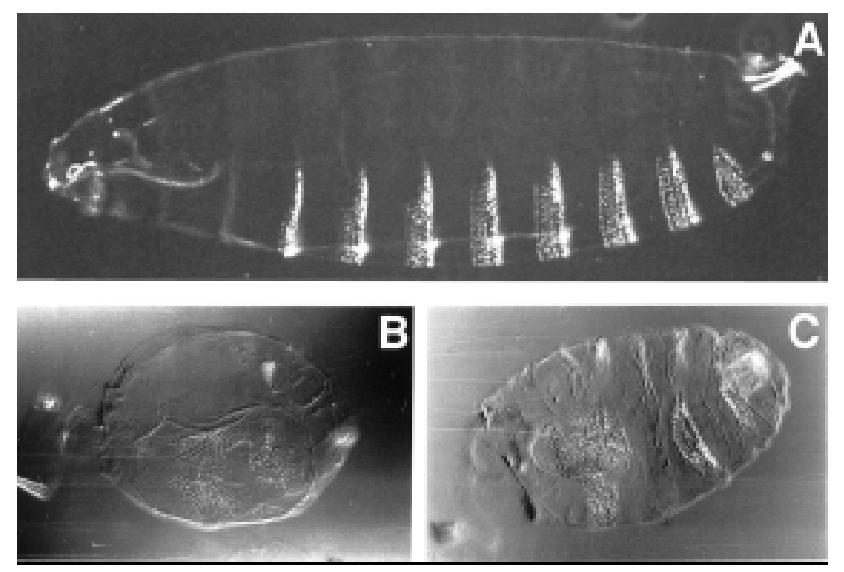

Figure 6. Chip ${ }^{\mathrm{e} .5}$ germ-line clone embryonic cuticles. All panels are the same magnification. Anterior is to the left; dorsal is to the top. The wild-type cuticle is a lateral view and the mutant cuticles are slightly ventral aspects. (A) Wild-type Oregon-R embryo; (B) Chip ${ }^{\text {e5.5 }}$ germ-line clone grown at $18^{\circ} \mathrm{C}$. (C) Chip ${ }^{e 5.5}$ germ-line clone grown at $25^{\circ} \mathrm{C}$.

quired for the activity of many enhancers, one might expect that homozygous mutants would be embryonic lethal. We considered the possibility that maternally loaded Chip mRNA allows survival into the larval stages. To test this, germ-line clones homozygous mutant for Chi $\mathrm{p}^{\mathrm{e} .5}$, which is the only lethal mutation on its chromosome, were generated with the dominant female sterile yeast flip recombinase system (Chou and Perrimon 1996). The embryos from Chi $\mathrm{p}^{\mathrm{e} .5}$ germ-line clones fail to hatch. The cuticles exhibit normal dorsal-ventral polarity, but severe segmentation defects. At $18^{\circ} \mathrm{C}$, most have a single fused, irregularly shaped patch of ventral denticles (Fig. 6B). At $25^{\circ} \mathrm{C}$, the phenotype is slightly less severe and most have a large fused denticle patch and one or two denticle bands resembling $A 7$ and $A 8$ of wild type (Fig. 6C). A few rare embryos at $25^{\circ} \mathrm{C}$ display a pairrule-like phenotype with approximately half the normal number of segments (not shown).

We tested whether a wild-type paternal allele could influence the phenotype of Chip ${ }^{\text {e5.5 }}$ germ-line cl one embryos. Germ-line mosaic females were mated to males with Chi $\mathrm{p}^{\mathrm{e} 5.5}$ on one chromosome and a P element containing a fushi tarazu (ftz)-lacZ fusion gene on the homolog with a wild-type $C$ hip allele. The resulting embryos were stained with anti- $\beta$-galactosidase anti bodies. We observed roughly equal numbers of staining and nonstaining developing embryos with indistinguishable segmentation defects (not shown), indicating that a wildtype paternal Chip allele does not substantially al ter development.

The unsegmented phenotype of Chip ${ }^{\text {e5.5 }}$ germ-line clone embryos resembles that displayed by embryos homozygous for null alleles of the pair-rule gene evenskipped (eve) (N üsslein-Volhard et al. 1985). To determine whether the phenotype reflects a lack of eve expression, we stained Chip ${ }^{5.5}$ germ-line clone embryos raised at $18^{\circ} \mathrm{C}$ with anti-Eve antibodies. Eve is expressed,

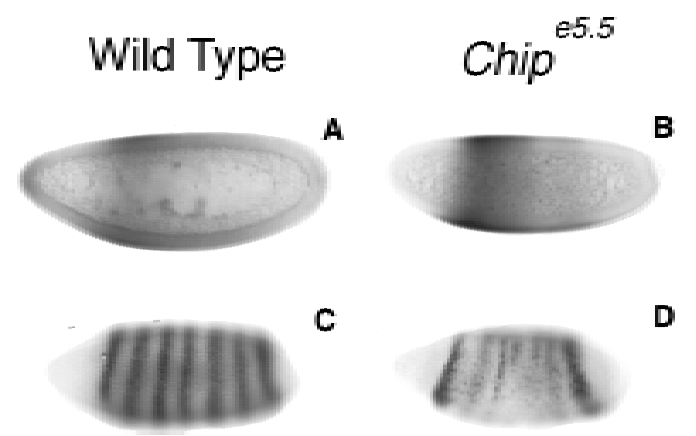

Figure 7. Expression of Eve in Chip ${ }^{\mathrm{e} .5}$ germ-line clone embryos. Embryos stained with anti-Eve antibodies. All are lateral views with anterior to the left and dorsal to the top. (A) Early wild-type cellular blastoderm. (B) Early Chi ${ }^{\text {e5.5 }}$ germ-line clone cellular blastoderm. Eve is overexpressed relative to wild-type. (C) Wild-type cellular blastoderm with seven stripes of Eve expression. (D) Chip ${ }^{\text {5.5 }}$ germ-line clone cellular blastoderm showing weak Eve expression.

although the pattern is abnormal. There are stripes (Fig 7D), but the number is often less than the seven in wild type (Fig. 7C). Furthermore, the first stripe to appear (Fig. 7B) is often wider and stronger than in wild type (Fig. 7A), whereas later-appearing stripes (Fig. 7D) are narrower, weaker, and more uneven than wild type (Fig. 7C). All seven stripes are affected, although the effects on stripes 1 and 7 are less dramatic.

The Eve expression defects are insufficient to explain the unsegmented phenotype of Chip ${ }^{\text {e5.5 }}$ germ-line clone embryos because hypomorphic eve mutations exhibit

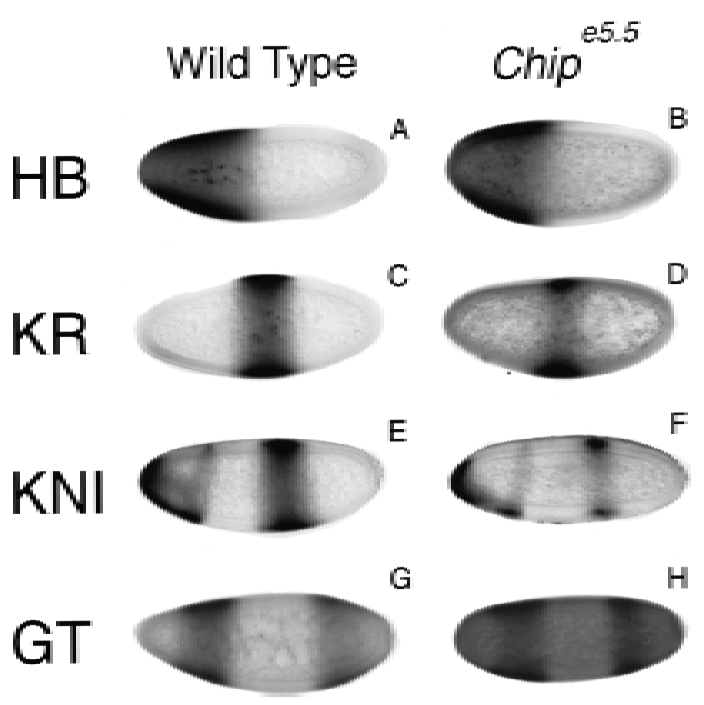

Figure 8. Expression of gap gene proteins in wild-type and Chip ${ }^{\text {e5.5 }}$ germ-line clone embryos. Cellular blastoderm embryos were stained with antibodies against the indicated gap proteins ( $\mathrm{Hb}, \mathrm{Kr}, \mathrm{Kni}$, and $\mathrm{Gt})$. All are lateral views with anterior to the left and dorsal to the top. (A,C,E,G) Wild type. (B,D,F,H) M utant embryos from $\mathrm{Chip}^{\mathrm{e} .5}$ germ-line clones. $\mathrm{Kr}$ and $\mathrm{Kni}$ expression is lower in the mutants, and the domain of Gt expression is expanded. 
pair-rule phenotypes (N üsslein-Vol hard et al. 1985). Embryos homozygous mutant for two pair-rule genes can al so have an unsegmented phenotype ( $\mathrm{N}$ üsslein-Volhard et al. 1985). Expression of a ftz-lacZ fusion gene, however, is al so only partial ly defective in Chi $\mathrm{p}^{\mathrm{e} .5}$ germ-line embryos, displaying an abnormal stripe pattern that alternates with the Eve pattern (not shown). This suggests that pair-rule gene defects alone are insufficient to explain the cuticle phenotype.

Pair-rule genes are regulated by gap genes. The observation that Eve and ftz-lacZ are expressed in abnormal alternating stripe patterns suggests that gap gene expression might also be partially defective in embryos lacking Chip activity. To confirm this, we stained Chi $\mathrm{p}^{\mathrm{e} .5} \mathrm{germ}$ line clone embryos incubated at $18^{\circ} \mathrm{C}$ with antibodies against the four gap proteins Krüppel $(\mathrm{Kr}), \mathrm{Knirps}(\mathrm{Kni})$, Giant (Gt), and Hunchback $(\mathrm{Hb})$. The $\mathrm{Hb}$ pattern is indistinguishable from wild type (Fig. 8A,B), and there are mild defects in the $\mathrm{Kr}$ and Kni patterns. At the cellular blastoderm stage, the $\mathrm{Kr}$ (Fig. 8C,D) and posterior Kni bands (Fig. 8E,F) are both slightly narrower, weaker, and more uneven in Chip ${ }^{\mathrm{e} .5}$ germ-line clone embryos than in wild-type. Despite these mild abnormalities, the expression patterns of these three gap genes indicate that the maternally derived anterior-posterior Bicoid and $\mathrm{N}$ anos protein gradients are present in embryos lacking active Chip.

Lack of active Chip affects Gt more severely than the other gap proteins. In wild-type precellular and early celIular blastoderm embryos, Gt is restricted to two broad bands (Fig. 8G), whereas in Chi p ${ }^{\mathrm{e} 5.5}$ germ-line cl one embryos, Gt is expressed at low to moderate levels in the entire embryo, including the pole cells (Fig. 8H). Expression in domains to which Gt is restricted in wild type varies from moderate to high. In later stages, when Gt resolves into multiple bands of expression in wild-type, Gt expression in mutant embryos is similar to wild type (not shown).

$M$ isexpression of $\mathrm{Gt}$ in embryos lacking active Chip can explain the decreased expression of $\mathrm{Kr}$ and $\mathrm{Kni}$ because Gt represses Kr and kni (Kraut and Levine 1991; Capovilla et al. 1992). Because Gt helps define the anterior border of Eve stripe 2 by repression (Small et al. 1991), it is conceivable that abnormal Gt expression also weakens Eve stripe 2. Misexpression of Gt, however, should not weaken other Eve stripes because some of these overlap wild-type Gt domains. We concl ude that at least some of the effects on Eve expression in embryos lacking active Chip are independent of the effects on Gt expression.

The observed defects in gap gene and eve expression would be more consistent with partial segmentation than the observed unsegmented cuticle phenotype. We postulate, therefore, that the mutant cuticle phenotype reflects expression defects in multiple genes at different levels in the segmentation pathway. Importantly, however, the effects on the expression of gap genes, among the first zygotic genes expressed, shows that Chip is required for accurate gene expression very early in development. The fact that embryos lacking active Chip ex- press segmentation genes also shows that Chip is not required for basal promoter activity.

\section{Discussion}

Chip is a unique general transcription factor

The Chip gene was identified in a genetic screen designed to identify factors that facilitate communication between remote enhancers and promoters (Morcillo et al. 1996a). We postulate that enhancer-facilitator proteins are not directly involved in the transcription activation reaction, but hel $p$ form chromatin structures that bring the enhancer and promoter closer together. We infer that Chip is a potential enhancer-facilitator because in Chip mutants, the Suhw protein that binds gypsy insertions and blocks enhancer-promoter communication can act interchromosomally to block the remote wing margin enhancer in the cut gene (M orcillo et al. 1996a).

The observations reported here support the view that Chip, as expected for an enhancer-facilitator, plays a general role in gene expression. Chip mRN A is present at all stages of development, and Chip is a virtually ubiquitous nuclear protein. In contrast, other transcription factors that support cut wing margin enhancer activity, such as Sd (Campbell et al. 1992; Williams et al. 1993) and Mam (Bettler et al. 1996; Schmid et al. 1996), are expressed in specific temporal and spatial patterns. Chip protein also associates with numerous sites along the entire lengths of the salivary gland polytene chromosomes as expected for a general factor, and in contrast to a more gene- and tissue-specific factor like $\mathrm{M}$ am, which associates with a limited number of sites (Bettler et al. 1996). Furthermore, reductions in Chip activity affect expression of diverse sets of genes at various stages of development, including gap genes, which are among the first genes expressed.

Chip is unlikely to be a basal transcription factor because lack of Chip activity does not cause a loss of promoter activity for any of the segmentation genes examined. However, mutations in the TATA-binding protein (TBP)-associated factors $\left(T_{A} F_{\mid I} S\right.$ ) associated with the basal transcription apparatus drastically reduce expression of some segmentation genes and have no effects on others (Sauer et al. 1996). Thus, we cannot entirely rule out the possibility that Chip is a basal factor that affects a promoter's response to specific enhancers, although this would not explain why reduced Chip activity allows interchromosomal enhancer blocking by Suhw.

The possibility that Chip creates an open chromatin structure, thereby improving the access of transcription factors to DNA, is also unlikely. In contrast to other factors proposed to have this function, such as the mod(mdg4) [E(var)3-93D] proteins (Dorn et al. 1993) or GAGA factor (Farkas et al. 1994), mutations reducing Chip activity do not modify the position effect variegation that occurs when chromosomal rearrangements place a euchromatic gene next to heterochromatin (M orcillo et al. 1996a).

The predicted amino acid sequence further supports 
that view that Chip plays a uni que rolein enhancer function because it is not homologous to any cloned transcription factors such as enhancer-binding proteins, basal factors, or coactivators, and does not contain any known protein motifs. Moreover, Chip homologs were detected in higher eukaryotes but not in yeast. Part of the motivation for the hypothesis that higher eukaryotes have factors that facilitate enhancer-promoter interactions is the observation that a yeast UAS can behave like an enhancer in higher eukaryotic cells but acts only promoter-proximal in yeast (Struhl 1989).

\section{Chip-LIM protein interactions in development}

The vertebrate homologs of Chip provide clues to some of Chip's molecular activities. The mouse Nli/Ldbl/ Clim-2, Xenopus XIdb1, and mouse Clim-1 proteins were isolated because they bind to LIM domains of nuclear proteins (Jurata et al. 1996; Agulnick et al. 1997; Bach et al. 1997). The LIM domain is a class of $\mathrm{Zn}^{2+}$ chelating protein motifs involved in a variety of proteinprotein interactions (for review, see Sanchez-Garcia and Rabbitts 1994; Dawid et al. 1995). LIM domains are found in both nuclear and cytoplasmic proteins and there are several subclasses of LIM domains. Many nuclear LIM domain proteins also contain the HD DNAbinding motif, whereas others (LMO proteins) consist primarily of LIM domains. NIi/Ldb1/Clim-2, Clim-1, and XIdb1 bind LIM domains of the subclass found in LIM-HD and nuclear LMO proteins (Agulnick et al. 1996; Jurata et al. 1996; Bach et al. 1997).

LIM domains appear to have negative effects on the activities of LIM-HD proteins. Thus, mutation or truncation of the LIM domains increases the DNA-binding activity of the Islet-1 (ISL-1) and M ec-3 LIM-HD proteins (Sanchez-Garcia et al. 1993; Xue et al . 1993). Mutation of the LIM domains also al lows injected XIim-1, a LIM-HD protein, to induce secondary axes in Xenopus development (Taira et al . 1994). Similar to mutation of the LIM domains, coinjection of the XIdbl Chip homolog with Xlim-1 leads to axis duplication (Agulnick et al. 1996). This suggests that binding of XIdbl overcomes the negative effects of the LIM domains.

Although the coinjection experiment indicates that XIdb1 can interact with Xlim-1 in vivo and affect development, it does not show that this interaction is required for normal development, or that XIdb1 is an essential protein. The homozygous larval lethality of mutant Chip alleles (M orcillo et al. 1996a) and the embryonic lethality of Chip ${ }^{\mathrm{e} 5.5}$ germ-line clones, therefore, is the first demonstration that a member of this class of LIM domain-binding proteins is an essential developmental factor. The interaction between Chip and the Ap LIM domains in a yeast double-hybrid fusion experiment shows that Chip is a functional homolog of $\mathrm{N} \mathrm{Ii/Ldbl/Clim-2,}$ Clim-1, and XIdb1. More importantly, the synergistic wing margin phenotype displayed by flies heterozygous for both apterous and Chip mutations indicates that the Chip-Ap interaction is normally required in vivo.
Do LIM domain and LIM domain-binding proteins have broad roles in gene expression and development?

Like Chip, XIdb1 is nuclear (Agulnick et al. 1996) and $\mathrm{Nli} / \mathrm{Ldbl} / \mathrm{Clim}-2$ is expressed in a variety of tissues (A gulnick et al. 1996; Jurata et al. 1996; Bach et al . 1997). In contrast, LIM domain proteins such as Ap and XIim-1 are expressed in ti ssue-specific patterns and have specific developmental tasks (for review, see Dawid et al. 1995). Curiously, Chip plays a key role in segmentation, yet no LIM domain proteins are known to be involved in segmentation. DImo, a LMO protein, is present during Drosophila embryogenesis (Zhu et al. 1995), but there are no DImo mutants and its functions are unknown. The direct targets of Chip regulati on during embryogenesis are unknown, but gt and eve are two candi dates on the basis of the evidence presented here; however, they are not known to be regulated by LIM domain proteins. Moreover, Chip regulates expression of cut and $U$ bx during imaginal disc development (Morcillo et al. 1996a), and these genes are also not known to be regulated by LIM domain proteins. It is possible, therefore, that LIM domain proteins play broader roles in development than appreciated previously, and that there are several unknown LIM domain proteins required for segmentation and imaginal disc development. Consistent with this idea, additional Drosophila LIM-HD proteins have recently been discovered. The Arrowhead protein is involved in establishment of some imaginal precursor cells (Curtiss and Heilig 1995, 1997a,b), the Islet protein governs axon pathfinding and neurotransmitter identity (Thor and Thomas 1997), and a Drosophila Lim-3 homolog is invol ved in embryonic nervous system development (A. Tomlinson, S. Thor, and J. Thomas, pers. comm.).

Another possible explanation for the broad functions of Chip is that it may interact with other proteins without LIM domains. The two mouse Chip homologs, N Ii/ Ldb1/Clim-2 and Clim-1 interact directly with P-Otx, a HD protein that lacks LIM domains (Bach et al. 1997). There are several non-LIM HD proteins involved in Drosophila segmentation and regulation of $\mathrm{Ubx}$, and it is feasible that Chip interacts with one or more of these proteins.

How do Chip and its homologs regulate enhancer activity?

LIM-HD proteins are likely to function like other homeodomain proteins. Because HD proteins are commonly thought of as activators and repressors that bind to enhancers, the interaction between Chip and the Ap LIM-HD protein appears at first to suggest that Chip is a coactivator. Recent evidence, however, indicates that the vertebrate Chip homologs may regulate interactions between different activator proteins. Both mouse Chip homologs potentiate synergistic activation of transcription by the P-LIM/LHX3 and P-Otx HD proteins in transfection experiments with reporter gene constructs (Bach et al. 1997). N li/Ldb1/Clim-2 also blocks syner- 
gistic activation by the Lmx1 LIM-HD and E47 basic helix-loop-helix (bHLH) proteins (Jurata and Gill 1997). $\mathrm{Nli} / \mathrm{Ldb} 1 / \mathrm{Clim}-2$ forms homodimers and higher order complexes with Lmx1 that contain multiple N Ii/Ldbl/ Clim-2 molecules (Jurata and Gill 1997), suggesting that it may also bridge together different activator proteins. Similarly, Nli/Ldbl/Clim-2 is a component of an erythroid DN A-binding compl ex containing the Lmo2 LIM only protein, the Tall and E47 bHLH proteins, and the Gata-1 zinc finger protein (Wadman et al. 1997). Thus Chip and its homologs may function at enhancers to bring together diverse transcription factors and form higher order activation complexes, and in some cases, to block formation of such complexes.

Although Chip and its homologs are likely to function at enhancers to regul ate interactions between diverse activator molecules, this alone cannot explain the genetic observation that, in contrast to an enhancer-binding factor, Chip is antagonistic to Suhw enhancer-blocking activity (M orcill o et al . 1996a). Enhancers blocked by Suhw can still activate another promoter in the other direction (Cai and Levine 1995; Scott and Geyer 1995), indicating that Suhw does not reduce the binding or activation potential of enhancer-binding factors. Therefore, the specific genetic antagonism between Chip and Suhw indicates that Chip plays an additional role in enhancerpromoter communication. Because Chip and its homologs interact with diverse HD proteins, it is al so of interest that HD proteins may have functions other than activation and repression. Homeodomain proteins bind DN A with low sequence specificity in vitro (Desplan et al. 1988; Hoey and Levine 1988; Walter and Biggin 1996). Strikingly, and in contrast to other transcription factors, all the HD proteins examined in vivo bind nearly uniformly throughout their genetical ly defined target genes, instead of to specific enhancers. In UV cross-linking experiments, Eve and Ftz bind throughout at least $10 \mathrm{~kb}$ of eve, as well as several kilobase pairs of $U$ bx and ftz (Walter et al. 1994; Walter and Biggin 1996). Similarly, in vivo formal dehyde cross-linking experiments reveal that the Abd-B homeodomain protein binds throughout several kilobase pairs of the empty spiracles gene (Orlando et al. 1997). Thus, it has been proposed that HD proteins may hel p organize the structure of regulatory regi ons through interactions between themselves and other proteins (Walter et al. 1994). Similar to the way they may function at enhancers, the Chip family of proteins may also mediate interactions between HD proteins to hel $p$ form structures that support interactions between distant regulatory el ements and their promoters.

\section{Materials and methods}

Screen for new Chip alleles

Approximately 220,000 progeny were screened after $\gamma$ ray mutagenesis for enhancers of the $\mathrm{ct}^{\mathrm{L}-32}$; su( $\left.\mathrm{Hw}\right)^{\mathrm{e} 2}$ cut wing phenotype as described previously (Morcillo et al. 1996a) except the second chromosome was marked with a $\left.\mathrm{P}^{\mathrm{W}} \mathrm{w}^{+}\right]$el ement at 57B. Three new Chip alleles: Chip ${ }^{96.1}$, Chip ${ }^{9230}$, and Chip ${ }^{9371}$ were identified. Chip ${ }^{\text {e5.5 }}$ was mapped to 2-106.8 by use of $P$ el ements as markers as described el sewhere (M orcillo et al. 1996a,b).

\section{Reversion of the I(2)k04405 P-element insertion}

I(2)k04405 males were crossed to females with the CyO, HOP2 transposase chromosome (provided by W. Gel bart, Harvard U niversity, Boston, MA). F1 CyO, HOP2/I(2)k04405 males were crossed to yellow* (y*) $w^{*} ; \mathrm{CyO}, \mathrm{Df}(2 \mathrm{R}) \mathrm{Kr} 4, \mathrm{Kr}^{\mathrm{B} 80}, \mathrm{Dp}(1 ; 2) \mathrm{y}^{+}$ females. Three independent $\mathrm{y}^{*} \mathrm{w}^{*} ; \mathrm{CyO}, \mathrm{Df}(2 \mathrm{R}) \mathrm{Kr} 4, \mathrm{Kr}^{\mathrm{B} 8}$, $\mathrm{Dp}(1 ; 2) \mathrm{y}^{+} / \mathrm{w}^{-} \mathrm{F} 2$ males were crossed to Chip ${ }^{9230} / \mathrm{CyO}$,' $\mathrm{Df}(2 \mathrm{R}) \mathrm{Kr} 4, \mathrm{Kr}^{\mathrm{B} 80}, \mathrm{Dp}(1 ; 2) \mathrm{y}^{+}$, and Chipe5.5/CyO, Df(2R)Kr4, $\mathrm{Kr}^{\mathrm{B} 80}, \mathrm{Dp}(1 ; 2) \mathrm{y}^{+}$females to test for complementation of Chip lethality.

Rescue of the I(2)k04405 P-element insertion from genomic DNA

The P-lacW (Bier et al. 1989) element in I(2)k04405 (T orok et al. 1993) was designed to be rescued by transformation of E. coli with genomic DN A. Three micrograms of genomic DNA from homozygous I (2)k04405 second instar larvae were di gested with Sacll, religated, and used to transform $\mathrm{DH} 5 \alpha \mathrm{E}$. coli. The rescued plasmid contains $\sim 4.5 \mathrm{~kb}$ of genomic DNA.

\section{Isolation of Chip genomic DNA}

P1 phage DN A was prepared as described by Hartl et al. (1994). Southern blots of EcoRI-digested P1 phage DN A were prepared as described in Sambrook et al. (1987). A 4.5-kb Hindlll fragment of the rescued I (2)k04405 plasmid containing the flanking genomic DNA was gel-purified, labeled with ${ }^{32} \mathrm{P}$ by random priming (Sambrook et al. 1987), and used as probe. A 10-kb fragment of the DS00543 P1 phage insert hybridizing to the probe was gel-purified and cloned into the EcoRI site of pBluescript (SK $\rightarrow$ (Stratagene). Several kilobase pairs around the Pinsertion site were sequenced with Sequenase v. 2 (U.S. Biochemical) according to the manufacturer's protocols.

\section{RNA preparation and Northern blots}

RNA isolation and N orthern blot hybridization were performed as described previously (Dorsett et al. 1989). Single-stranded ${ }^{32} \mathrm{P}-$-labeled RN A probes were prepared with the 1-kb EcoO109BamHI fragment (Fig. 2A) as template. Northern blots were quantitated with a PhosphorImager. As an internal standard, rRNA was quantitated by densitometric scanning of a photographic negative.

\section{P-element rescue of Chip}

A 7.4-kb Bglll-EcoRI fragment (Fig. 2A) was cloned into the BamHI and EcoRI sites of pCasper (Pirrotta 1988). The resulting plasmid was used for $\mathrm{P}$ element-mediated germ-line transformation (Rubin and Spradling 1982). Transformant flies were crossed to Chip ${ }^{\text {e5.5 }}$ flies to test for complementation of Chip lethality.

\section{Chip cDNA cloning}

A third instar imaginal disc cDN A library in $\lambda$ gt10 (provided by J. Kim, University of Wisconsin, Madison) was screened by use of standard protocols (Sambrook et al. 1987) with probes prepared by random-priming of the 1-kb EcoO109-BamHI genomic DN A fragment (Fig. 2A). Eight hybridizing plaques were plaquepurified and DNA prepared. The EcoRI inserts were cloned into 
pBluescript (SK - ), restriction mapped, and full-length clones were sequenced.

\section{Sequencing of Chip mutant alleles}

The Chip ORF was amplified from genomic DNA isolated as described elsewhere (Levis et al. 1982) from homozygous mutant Chip ${ }^{\text {5.5 }}$, Chip ${ }^{91}$, and Chi ${ }^{9371}$ second instar larvae by PCR [primer 1 (5'-ATTAGAATTCATGAATCGTAGGGGTTTGAA-3') and primer 2 (5'-ATTAAGATCTGTGTGTAGAGTAGACGAC-3')] (Saiki et al. 1988). Amplified DNA was digested with BglII and EcoRI, cloned into the BamHI and EcoRI sites of pBluescript (SK - ), and sequenced.

\section{Genetic interaction between Chip and ap}

$\mathrm{y}^{*} \mathrm{w}^{*}$; CyO, Df(2R)Kr4, Kr ${ }^{\mathrm{B} 80}, \mathrm{Dp}(1 ; 2) \mathrm{y}^{+} / \mathrm{Chip}^{\mathrm{e} .5}$ flies were crossed to $y^{*} w^{*} ; \mathrm{CyO}, \mathrm{Df}(2 \mathrm{R}) \mathrm{Kr} 4, \mathrm{Kr}^{\mathrm{B80}}, \mathrm{Dp}(1 ; 2) \mathrm{y}^{+} / \mathrm{ap}^{56 \mathrm{fl}}$ flies at $25^{\circ} \mathrm{C}$. The mutant wing margin phenotype of $\mathrm{F} 1$ males displaying a y phenotype was quantitated by scoring for nicks as described previously (Morcillo et al. 1996a).

\section{Yeast double-hybrid fusion experiments}

Yeast double-hybrid fusion experiments were conducted as described by Bartel and Fiel ds (1995). The Chip ORF was amplified by PCR (primer 1 and primer 2), digested with BgllI and EcoRI, and cloned into the BamHI and EcoRI sites of pBTM 116 (Bartel and Fields 1995), fusing it to the carboxyl terminus of the bacterial lexA reading frame. The segment of ap encoding the two LIM domains (Cohen et al. 1992) was amplified by PCR [primer 3 (5'-ATTAGGATCCAGCAAAATAACGCGCAACG-3') and primer 4 (5'-ATTAGGATCCCGGTTAGGTGGCGCTCAT-3')] from a cDNA clone (provided by D. Segal, University of Tel A viv, Israel), digested with BamHI, and cloned into the BamHI site of pGAD10 (provided by S. Fields, University of Washington, Seattle), thereby fusing the Gal 4 activation domain to the amino terminus of the LIM domains. To provide a control plasmid, the Chip ORF was amplified by PCR [primer 2 and primer 5 (5'-ATTAAGATCTATGAATCGTAGGGGTTTGAA-3')], digested with BglII, and cloned into the BamHI site of pGADI0. L40 yeast (MATa, his3 200 , trp1-901, leu2-3,112, ade2, LYS:: (lexAop) ${ }_{4}$-HIS3, URA3::(lexAop) $)_{8}-\mathrm{lacZ}$ ) (Hollenberg et al. 1995) were transformed by use of the LiCl method (Sherman et al. 1986) with the indicated plasmids by selection on leucine and tryptophan double omission plates containing $2 \%$ glucose (Sherman et al. 1986) at $30^{\circ} \mathrm{C}$. To eval uate lacZ reporter expression, colonies were stained with X-Gal. Activation of the HIS3 reporter was evaluated by growth on leucine, tryptophan, and histidine triple omission plates at $25^{\circ} \mathrm{C}$.

\section{Expression of Chip in E. coli and antibody preparation}

Chip protein was expressed in E. coli as a fusion with glutathione S-transferase (GST). Part of the Chip CDNA open reading was amplified by PCR from a CDNA clone [primer 5 and primer 6 (5'-ATTAGAATTCAACGCTTCTGGTTCGTCACA$\left.3^{\prime}\right)$ ]. The 1.4-kb PCR product was digested with BgllI and EcoRI and cloned into the BamHI and EcoRI sites of pGEX-2T (Pharmacia Biotech). The BamHI-EcoRI fragment of the resulting clone was replaced by the $0.7-\mathrm{kb}$ BamHI-EcoRI fragment of the Chip CDNA clone to produce the expression plasmid.

Seven liters of DH $5 \alpha$ E. coli with the Chip expression plasmid were grown to saturation in Luria broth at $30^{\circ} \mathrm{C}$ and protein expression induced by $0.5 \mathrm{~mm}$ IPTG for $3 \mathrm{hr}$. All subsequent steps were conducted at $4^{\circ} \mathrm{C}$. The E. coli pellets were suspended in $11 \mathrm{ml} /$ liter of culture in EB [20 mM HEPES at pH 7.5, $0.1 \mathrm{~m}$ $\mathrm{NaCl}, 1 \mathrm{~mm}$ 2-mercaptoethanol, 0.1\% NP-40, $50 \mathrm{~mm}$ phenylmethylsulfonyl fluoride (PMSF), $1 \mu \mathrm{g} / \mathrm{ml}$ each of leupeptin and pepstatin, $2 \mu \mathrm{g} / \mathrm{ml}$ of aprotinin, $10 \%$ glycerol ]. The cells were lysed by sonication, and the lysate was clarified by centrifugation at $13,000 \mathrm{~g}$ for $15 \mathrm{~min}$. The pellet was suspended in EB, sonicated, clarified by centrifugation, and the two supernatants were pooled. The supernatant was incubated with $4 \mathrm{ml}$ glutathione-agarose beads (Sigma, equilibrated with EB) overnight with gentle agitation. The beads were washed twice with $50 \mathrm{ml}$ of EB for $10 \mathrm{~min}$, twice with TB $(20 \mathrm{~mm}$ Tris- $\mathrm{HCl}$ at $\mathrm{pH} 8.4,0.15$ $\mathrm{M} \mathrm{N} \mathrm{aCl}, 1 \mathrm{~mm}$ 2-mercaptoethanol, and 10\% glycerol), and twice with TB containing $0.1 \mathrm{M} \mathrm{CaCl}_{2}$. The beads were suspended in $6 \mathrm{ml}$ of TB containing $0.1 \mathrm{M} \mathrm{CaCl}_{2}$ and Chip protein eluted by thrombin cleavage. Fresh thrombin $(1.5 \mathrm{U} / \mathrm{ml})$ was added every hour during the $3-\mathrm{hr}$ incubation at $25^{\circ} \mathrm{C}$ with gentle agitation. PMSF (1 mM) and EDTA (2 mm) were added prior to dialysis of the supernatant against 100 volumes of $25 \mathrm{~mm}$ HEPES at $\mathrm{pH} 7.5$, $50 \mathrm{~mm} \mathrm{KCl}, 5 \mathrm{~mm} \mathrm{M} \mathrm{gCl}, 0.1 \mathrm{~mm}$ EDTA, $1 \mathrm{~mm}$ dithiothreitol, and $0.2 \mathrm{~mm}$ PMSF, and then against the same buffer lacking PMSF. The dialysate was concentrated with a Centricon filter. The final extract $(0.6 \mathrm{ml})$ contained $1.44 \mathrm{mg} / \mathrm{ml}$ of protein, $\sim 40 \%$ Chip, as estimated by SDS-PAGE. The major contaminant appeared to be E. coli GroEL.

E. coli Chip was used as antigen in rabbits at the Pocono Rabbit Farm and Laboratory (Canandensis, PA) according to their standard purified protein antigen protocol. The anti-Chip antibodies were affinity-purified from crude serum on a Western blot of an SDS-PAGE separation of bacterial Chip extract as described elsewhere (Harlow and Lane 1988). The purified antibody was dialyzed overnight at $4^{\circ} \mathrm{C}$ against buffer containing 50 $\mathrm{mm}$ Tris- $\mathrm{HCl}$ at $\mathrm{pH} 7.5,0.1 \mathrm{M} \mathrm{NaCl}, 1 \mathrm{~mm}$ EDTA, and $10 \%$ glycerol. Glycerol was added to bring the final concentration to $50 \%$ and the purified antibody stored at $-20^{\circ} \mathrm{C}$.

\section{Antibody staining}

Embryos were dechorionated with bleach and fixed in a 1:1 solution of heptane and $4 \%$ paraformal dehyde in PBS (1 mM $\mathrm{KH}_{2} \mathrm{PO}_{4}, 10 \mathrm{~mm} \mathrm{Na}_{2} \mathrm{HPO}_{4}, 137 \mathrm{~mm} \mathrm{NaCl}$, and $2.7 \mathrm{~mm} \mathrm{KCl}_{2}$, at $\mathrm{pH} 7.0$ ) for $20 \mathrm{~min}$ with gentle agitation. The embryos were washed with heptane, devitellinized with a 1:1 mix of heptane and methanol, and dehydrated with methanol. Larval tissues were dissected in cold PBS $(\mathrm{pH} 7.2)$ containing $0.3 \%$ Triton $X-100$, fixed in PBS (pH 7.2) containing 4\% paraformal dehyde, and dehydrated in methanol. Embryos and larval tissues were rehydrated in PBST (pH 7.4 PBS containing 0.3\% Triton X-100), blocked with PBST containing $0.5 \%$ bovine serum albumin (PBSTB) for $30 \mathrm{~min}$, and incubated with primary antibodies overnight at $4^{\circ} \mathrm{C}$ in PBST B with gentle agitation. After several washes in PBST and blocking with PBSTB for $30 \mathrm{~min}$, the tissues were incubated with a 1:200 dilution of the secondary antibodies (Vector Laboratories) for $45 \mathrm{~min}$. The colorimetric reaction was conducted according to instructions provided with the Vectastain kit (Vector Laboratories). The anti-Eve (provided by $\mathrm{Y}$. Hiromi, Princeton University, NJ) and anti- $\beta$-galactosidase antibodies were used as described previously (Baylies et al . 1995) and affinity-purified anti-Chip antibody was diluted 1 : 100. For the anti-gap protein antibodies (provided by J. Reinitz, Mount Sinai Medical School, N ew York, NY) the following dilutions were used: $\mathrm{Hb}, 1: 2000 ; \mathrm{Kr}$, 1:2000; Kni, 1:1000, and Gt, 1:2000. Embryos and larval tissues were mounted in araldite and photographed with a $20 \times$ objective and bright-field or Nomarski optics. Salivary gland nuclei were photographed with bright field optics with a $100 \times$ oil immersion objective and a $2 \times$ Barlow lens. 
Generation of germ-line clones and cuticle preparation

Female $y^{1} w^{1118} P\left\{y^{+t 7.2}=h s F L P\right\} 1 ; P\left\{w^{+m w . h s} \Rightarrow w^{\text {hs }}>\right\} G 13$

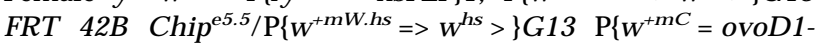
182R $1 \mathrm{P}\left\{\mathrm{w}^{\mathrm{tmC}}=0 \mathrm{voD} 1-18\right\} 2 \mathrm{R} 2$ third instar larvae were heat shocked to generate germ-line clones as described by others (Chou and Perrimon 1996). Eclosing females were mated to males heterozygous for $C$ hip $\mathrm{p}^{\mathrm{e} 5.5}$ and embryos collected on apple juice agar plates. Cuticles were prepared by dechorionating and devitellinizing embryos as described above. Devitellinized embryos were rehydrated twice with PBST, and clarified by addition of a 1:1 solution of Hoyer's medium (A shburner 1989) and $85 \%$ lactic acid and incubation at $70^{\circ} \mathrm{C}$ overnight. Mutant cuticles were photographed by use of $\mathrm{N}$ omarski optics with a $20 \times$ objective and wild-type cuticles were photographed with dark field optics.

\section{Acknowledgments}

We thank Bruce Reed for generously sharing unpublished re sults, confirming the Chip ${ }^{9230}$ breakpoints, and providing several fly stocks; Kathy Matthews and Bill Gelbart for providing flies; Jaeseob Kim and Sean Carroll for providing an imaginal disc CDN A library and P1 phages; Rob and Yvonne DeLotto for assistance with microinjections; David Weisbrot for assistance in PCR of Chip mutants; Danny Segal and Steve Cohen for ap cDN A clones; Kathryn Anderson for hel pful discussions, analysis of the Chip embryonic phenotype, and hel pful comments on the manuscript; John Reinitz and Yash Hiromi for providing anti-gap and anti-Eve antibodies; and Steve Small for helpful discussions about Eve expression and comments on the manuscript. This work was supported by $\mathrm{N}$ ational Science Foundation research grant 9404771 to D.D. and $N$ ational Institutes of Heal th Cancer Center Support grant N CI-P30-CA-08748 to M emorial Sloan-Kettering Cancer Center. The sequence data described in this paper were deposited in GenBank under accession numbers AF010325-AF010328.

The publication costs of this article were defrayed in part by payment of page charges. This article must therefore be hereby marked "advertisement" in accordance with 18 USC section 1734 solely to indicate this fact.

\section{References}

Agulnick, A.D., M. Taira, J.J. Breen, T. Tanaka, I.B. Dawid, and H. Westphal. 1996. Interactions of the LIM-domain binding factor Ldb1 with LIM homeodomain proteins. Nature 384: 270-272.

Ashburner, M. 1989. Drosophila: A laboratory manual. Cold Spring Harbor Laboratory Press, Cold Spring Harbor, NY.

Bach, I., C. Carriere, H. P. Ostendorff, B. Andersen, and M. G. Rosenfeld. 1997. A family of LIM domain-associated cofactors confer transcriptional synergism between LIM and Otx homeodomain proteins. Genes \& Dev. 11: 1370-1380.

Bartel, P.L. and S. Fields. 1995. Analyzing protein-protein interactions using two-hybrid system. Methods Enzymol. 254: 241-263.

Baylies, M.K., A. Martinez-Arias, and M. Bate. 1995. wingless is required for the formation of a subset of muscle founder cells during Drosophila embryogenesis. Devel opment 121: 38293837.

Bettler, D., S. Pearson, and B. Yedvobnick. 1996. The nuclear protein encoded by the Drosophila neurogenic gene mastermind is widely expressed and associates with specific chromosomal regions. Genetics 143: 859-875.
Bier, E., H. Vaessin, S. Shepherd, K. Lee, K. M cCall, S. Barbel, L. Ackerman, R. Carretto, T. Uemura, E. Grell, L.Y. Jan, and Y.N. Jan. 1989. Searching for pattern and mutation in the Drosophila genome with a P-lacZ vector. Genes \& Dev. 3: $1273-1287$.

Blair, S.S. 1993. Mechanisms of compartment formation: Evidence that non-proliferating cells do not play a critical role in defining the $\mathrm{D} / \mathrm{V}$ lineage restriction in the developing wing of Drosophila. Development 119: 339-351.

Bourgouin, C., S.E. Lundgren, and J.B. Thomas. 1992. apterous is a Drosophila LIM domain gene required for the devel opment of a subset of embryonic muscles. Neuron 9: 549-561.

Cai, H. and M. Levine. 1995. M odulation of enhancer-promoter interactions by insulators in the Drosophila embryo. Nature 376: 533-536.

Campbell, S., M. Inamdar, V. Rodrigues, V. Raghavan, M. Palazzolo, and A. Chovnick. 1992. The scalloped gene encodes a novel, evolutionarily conserved transcription factor required for sensory organ differentiation in Drosophila. Genes \& Dev. 6: 367-379.

Capovilla, M., E.D. Eldon, and V. Pirrotta. 1992. The giant gene of Drosophila encodes a b-ZIP DNA-binding protein that regulates the expression of other segmentation gap genes. Development 114: 99-112.

Chou, T.B. and N. Perrimon. 1996. The autosomal FLP-DFS technique for generating germline mosaics in Drosophila melanogaster. Genetics 144: 1673-1679.

Cohen, B., M.E. M cGuffin, C. Pfeifle, D. Segal, and S.M. Cohen. 1992. apterous, a gene required for imaginal disc development in Drosophila encodes a member of the LIM family of developmental regulatory proteins. Genes \& Dev. 6: 715729.

Curtiss, J. and J.S. Heilig. 1995. Establishment of Drosophila imaginal precursor cells is controlled by the Arrowhead gene. Development 121: 3819-3825.

-_- 1997a. Arrowhead encodes a LIM homeodomain protein that distinguishes subsets of Drosophila imaginal cells. Dev. Biol. (in press).

_-_. 1997b. DelIMiting development. BioEssays (in press).

Dawid, I.B., R. Toyama, and M. Taira. 1995. LIM domain proteins. C.R. Acad. Sci. Paris 318: 295-306.

Desplan, C., J. Theis, and P.H. O'Farrell. 1988. The sequence specificity of homeodomain-DNA interaction. Cell 54: 1081-1090.

Dorn, R., V. Krauss, G. Reuter, and H. Saumweber. 1993. The enhancer of position-effect variegation of Drosophila, $E(v a r) 3-93 D$, codes for a chromatin protein containing a conserved domain common to several transcriptional regulators. Proc. Natl. Acad. Sci. 90: 11376-11380.

Dorsett, D. 1990. Potentiation of a polyadenylylation site by a downstream protein-DN A interaction. Proc. Natl. Acad. Sci. 87: 4373-4377.

- - - 1993. Distance-independent inactivation of an enhancer by the suppressor of Hairy-wing DNA-binding protein of Drosophila. Genetics 134: 1135-1144.

- - - 1996. The suppressor of Hairy-wing protein and long distance enhancer promoter interactions. Mol. Cells 6: 381387.

Dorsett, D., G.A. Viglianti, B.J. Rutledge, and M. Meselson. 1989. Alteration of hsp82 gene expression by the gypsy transposon and suppressor genes in Drosophila melanogaster. Genes \& Dev. 3: 454-468.

Farkas, G., J. Gausz, M. Galloni, G. Reuter, H. Gyurkovics, and F. Karch. 1994. The Trithorax-like gene encodes the Drosophila GAGA factor. Nature 371: 806-808.

Geyer, P.K. 1997. The role of insulator elements in defining 
domains of gene expression. Curr. Opin. Genet. Dev. 7: 242248.

Harlow, E. and D. Lane. 1988. Antibodies: A laboratory manual. Cold Spring Harbor Laboratory, Cold Spring Harbor, NY.

Harrison, D.A., D.A. Gdula, R.S. Coyne, and V.G. Corces. 1993. A leucine zipper domain of the suppressor of Hairy-wing protein mediates its repressive effect on enhancer function. Genes \& Dev. 7: 1966-1978.

Hartl, D.L., D.I. N urminsky, R.W. Jones, and E.R. Lozovskaya. 1994. Genome structure and evolution in Drosophila: Applications of the framework P1 map. Proc. Natl. Acad. Sci. 91: 6824-6829.

Hoey, T. and M. Levine. 1988. Divergent homeo box proteins recognize similar DNA sequences in Drosophila. Nature 332: 858-861.

Hollenberg, S.M., R. Sternglanz, P.F. Cheng, and H. Weintraub. 1995. Identification of a new family of tissue-specific basic helix-loop-helix proteins with a two-hybrid system. Mol. Cell. Biol. 15: 3813-3822.

Jack, J., D. Dorsett, Y. DeLotto, and S. Liu. 1991. Expression of the cut locus in the Drosophila wing margin is required for cell type specification and is regulated by a distant enhancer. Development 113: 735-747.

Jurata, L.W. and G.N. Gill. 1997. Functional analysis of the nuclear LIM domain interactor, NLI. Mol. Cell. Biol. (in press).

Jurata, L.W., D.A. Kenney, and G.N. Gill. 1996. Nuclear LIM interactor, a rhombotin and LIM homeodomain interacting protein, is expressed early in neuronal development. Proc. Natl. Acad. Sci. 93: 11693-11698.

Kim, J., B. Shen, and D. Dorsett. 1993. The Drosophila melanogaster suppressor of Hairy-wing zinc finger protein has minimal effects on gene expression in Saccharomyces cerevisiae. Genetics 135: 343-355.

Kim, J., B. Shen, C. Rosen, and D. Dorsett. 1996. The DN Abinding and enhancer-blocking domains of the Drosophila suppressor of Hairy-wing protein. Mol. Cell. Biol. 16: 33813392.

Kraut, R. and M. Levine. 1991. M utually repressive interactions between the gap genes giant and Kruppel define middle body regions of the Drosophila embryo. Development 111: 611622.

Levis, R., P.M. Bingham, and G.M. Rubin. 1982. Physical map of the white locus of Drosophila melanogaster. Proc. Natl. Acad. Sci. 79: 564-568.

M orcillo, P., C. Rosen, and D. Dorsett. 1996a. Genes regulating the remote wing margin enhancer in the Drosophila cut Iocus. Genetics 144: 1143-1154.

Morcillo, P., R. Tuttle, and R.J. Maclntyre. 1996b. The use of transposable P-elements of Drosophila melanogaster for introductory genetics laboratory courses. J. Hered. 87: 399403.

N üsslein-Volhard, C., H. Kluding, and G. Jurgens. 1985. Genes affecting the segmental subdivision of the Drosophila embryo. Cold Spring Harbor Symp. Quant. Biol. 50: 145-154.

Orlando, V., H. Strutt, and R. Paro. 1997. A nalysis of chromatin structure by in vivo formaldehyde cross-linking. Methods 11: 205-214.

Pirrotta, V. 1988. Vectors for P-mediated transformation in Drosophila. BioTechnology 10: 437-456.

Rubin, G.M. and A. Spradling. 1982. Genetic transformation of Drosophila with transposable element vectors. Science 213: 348-353.

Saiki, R.K., D.H. Gelfand, S. Stoffel, S.J. Scharf, R. Higuchi, G.T. Horn, K.B. Mullis, and H.A. Erlich. 1988. Primer-directed enzymatic amplification of DN A with a thermostable DNA polymerase. Science 239: 487-491.

Sambrook, J., E.F. Fritsch, and T. Maniatis. 1987. Molecular cloning: A laboratory manual. Cold Spring Harbor Laboratory, Cold Spring Harbor, NY.

Sanchez-Garcia, I., H. Osada, A. Forster, and T.H. Rabbitts. 1993. The cysteine-rich LIM domains inhibit DNA binding by the associated homeodomain in Isl-1. EMBO J. 12: 42434250.

Sauer, F., D.A. Wassarman, G.M. Rubin, and R. Tjian. 1996. $\mathrm{TAF}_{\mid \mathrm{I}} \mathrm{S}$ mediate activation of transcription in the Drosophila embryo. Cell 87: 1271-1284.

Schimd, A.T., T.L. Tinley, and B. Yedvobnick. 1996. Transcription of the neurogenic gene mastermind during Drosophila development. J. Exp. Zool. 274: 207-220.

Scott, K.S. and P.K. Geyer. 1995. Effects of the su(Hw) insulator protein on the expression of the divergently transcribed Drosophila yolk protein genes. EMBO J. 14: 6258-6267.

Shen, B., J. Kim, and D. Dorsett. 1994. The enhancer-blocking suppressor of Hairy-wing zinc finger protein of Drosophila melanogaster alters DNA structure. Mol. Cell. Biol. 14: 5645-5652.

Sherman, F., G. Fink, and J. Hicks. 1986. Methods in yeast genetics. Cold Spring Harbor Laboratory, Cold Spring Harbor, NY.

Small, S., R. Kraut, T. Hoey, R. Warrior, and M. Levine. 1991. Transcriptional regulation of a pair-rule stripe in Drosophila. Genes \& Dev. 5: 827-839.

Struhl, K. 1989. Molecular mechanisms of transcriptional regulation in yeast. Annu. Rev. Biochem. 58: 1051-1077.

Taira, M., H. Otani, J.-P. Saint-Jeannet, and I.B. Dawid. 1994. Role of the LIM class homeodomain protein XIim- 1 in neural and muscle induction by the Spemann organizer in Xenopus. Nature 372: 677-679.

Thor, S. and J.B. Thomas. 1997. The Drosophila islet gene governs axon pathfinding and neurotransmitter identity. Neuron 18: 397-409.

Torok, T., G. Tick, M. Alvarado, and I. Kiss. 1993. P-lacW insertional mutagenesis on the second chromosome of Drosophila melanogaster: Isolation of lethals with different overgrowth phenotypes. Genetics 135: 71-80.

Wadman, I.A., H. Osada, G.G. Grutz, A.D. Agulnick, H. Westphal, A. Forster, and T.H. Rabbitts. 1997. The LIM-only protein Lmo2 is a bridging molecule assembling an erythroid, DNA-binding complex which includes the TAL1, E47, GATA-1 and Ldb1/N LI proteins. EMBO J. 16: 3145-3157.

Walter, J. and M.D. Biggin. 1996. DNA binding specificity of two homeodomain proteins in vitro and in Drosophila embryos. Proc. Natl. Acad. Sci. 93: 2680-2685.

Walter, J., C.A. Dever, and M.D. Biggin. 1994. Two homeo domain proteins bind with similar specificity to a wide range of DNA sites in Drosophila embryos. Genes \& Dev. 8: 16781692.

Williams, J.A., S.W. Paddock, and S.B. Carroll. 1993. Pattern formation in a secondary field: A hierarchy of regulatory genes subdivides the developing Drosophila wing disc into discrete subregions. Development 117: 571-584.

Xue, D., Y. Tu, and M. Chalfie. 1993. Cooperative interactions between the Caenorhabditis el egans homeoproteins UNC86 and MEC-3. Science 261: 1324-1328.

Zhu, T.H., J. Bodem, E. Keppel, R. Paro, and B. Royer-Pokora. 1995. A single ancestral gene of the human LIM domain oncogene family LMO in Drosophila: Characterization of the Drosophila DImo gene. Oncogene 11: 1283-1290. 


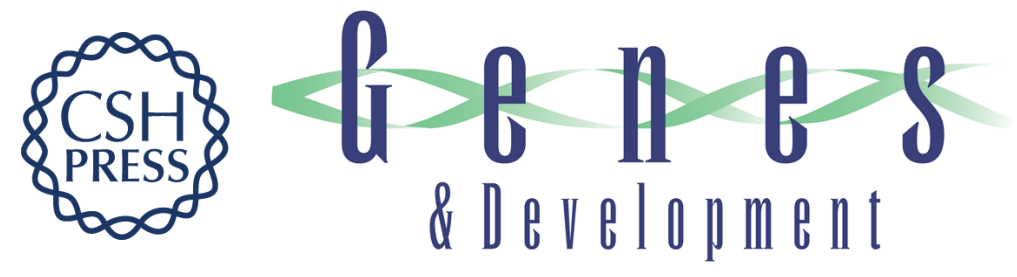

\section{Chip, a widely expressed chromosomal protein required for segmentation and activity of a remote wing margin enhancer in Drosophila}

Patrick Morcillo, Christina Rosen, Mary K. Baylies, et al.

Genes Dev. 1997, 11:

Access the most recent version at doi:10.1101/gad.11.20.2729

References This article cites 55 articles, 33 of which can be accessed free at:

http://genesdev.cshlp.org/content/11/20/2729.full.html\#ref-list-1

License

Email Alerting Receive free email alerts when new articles cite this article - sign up in the box at the top

Service right corner of the article or click here.

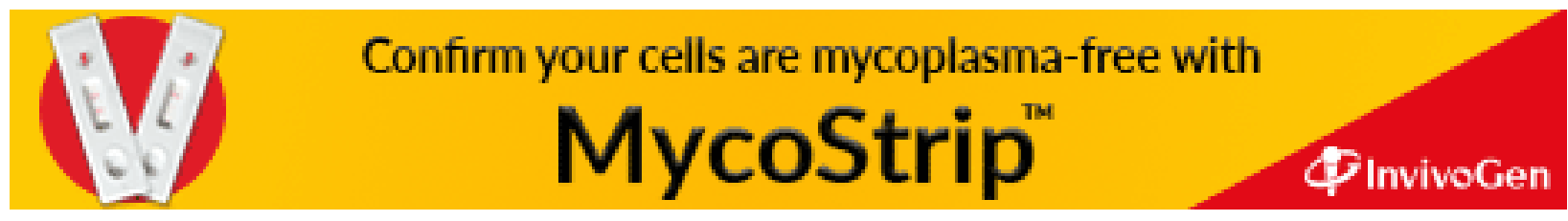

